University of Nebraska - Lincoln

DigitalCommons@University of Nebraska - Lincoln

Publications from USDA-ARS / UNL Faculty

U.S. Department of Agriculture: Agricultural

Research Service, Lincoln, Nebraska

2006

\title{
Post-Weaning Performance of Steers from Varying Calving and Weaning Strategies in Montana
}

\author{
E. E. Grings \\ USDA-ARS Fort Keogh Livestock and Range Research Laboratory
}

W. A. Phillips

USDA-ARS, Grazinglands Research Laboratory

R. E. Short

USDA-ARS Fort Keogh Livestock and Range Research Laboratory

H. Mayeux

USDA-ARS, Grazinglands Research Laboratory

R. K. Heitschmidt

USDA-ARS Fort Keogh Livestock and Range Research Laboratory

Follow this and additional works at: https://digitalcommons.unl.edu/usdaarsfacpub

Part of the Agricultural Science Commons

Grings, E. E.; Phillips, W. A.; Short, R. E.; Mayeux, H.; and Heitschmidt, R. K., "Post-Weaning Performance of Steers from Varying Calving and Weaning Strategies in Montana" (2006). Publications from USDA-ARS / UNL Faculty. 852.

https://digitalcommons.unl.edu/usdaarsfacpub/852

This Article is brought to you for free and open access by the U.S. Department of Agriculture: Agricultural Research Service, Lincoln, Nebraska at DigitalCommons@University of Nebraska - Lincoln. It has been accepted for inclusion in Publications from USDA-ARS / UNL Faculty by an authorized administrator of DigitalCommons@University of Nebraska - Lincoln. 


\title{
Prit \\ ost-Weaning Performance of Steers from Varying Calving and Weaning Strategies in Montana ${ }^{1}$
}

\author{
E. E. GRINGS, ${ }^{* 2}$ W. A. PHILLIPS, $\dagger$ PAS, R. E. SHORT, ${ }^{* 3}$ H. MAYEUX, $\dagger$ and R. K. HEITSCHMIDT* \\ *USDA-ARS Fort Keogh Livestock and Range Research Laboratory, Miles City, MT 59301, and †USDA- \\ ARS, Grazinglands Research Laboratory, El Reno, OK 73036
}

\section{Abstract}

The impact of varied calving and weaning times on post-weaning production of steer calves was evaluated in a 3yr study. Steers (approximately 12 steers per calving-weaning treatment per year) born in late winter or early spring were weaned at 190 or $240 d$ of age, and steers born in late spring were weaned at 140 or 190 d of age after grazing with their dams on native range. Steers were pen-fed a growing diet until approximately $375 \mathrm{~kg} \mathrm{BW}$. They were then moved to an individual feeding facility and fed a higher-energy diet. Steers were allotted to harvest dates based upon visual estimates of degree of fat cover. Mixed model procedures were used to evaluate fixed effects of treatment and random effects of year and year $\times$ treat-

\footnotetext{
${ }^{1}$ This research was conducted under a cooperative agreement between USDA-ARS and the Montana Agric. Exp. Sta. USDA-ARS is an equal opportunity and affirmative action employer and all agency services are available without discrimination. Mention of a proprietary product does not constitute a guarantee or warranty of the product by USDA, Montana Agric. Exp. Sta., or the authors and does not imply its approval to the exclusion of other products that may also be suitable.

${ }^{2}$ To whom correspondence should be addressed: elaine@larrl.ars.usda.gov ${ }^{3}$ Retired.
}

ment. Predefined contrasts were used to delineate treatment effects. Initial steer $B W$ was affected by calving system and age at weaning. No treatment differences in $A D G$ during the growing phase or $A D G$, feed intake, or feed efficiency during the finishing phase occurred. Steers averaged $537 \pm 4 \mathrm{~kg}$ at harvest and age at harvest did not differ among treatments. Late winter steers had greater hot carcass weights, marbling scores, and quality grades than early spring steers. Calving later in the calendar year without altering weaning times produced younger calves at weaning with lighter $B W$ at the start of the feeding period, which required greater number of days from weaning to harvest and produced carcasses with less marbling and lesser quality grades.

Key words: calving season, weaning, growth, beef cattle

\section{Introduction}

Calves from various calving seasons and weaning strategies may differ in BW at weaning in rangeland-based production systems (Grings et al., 2005). Profitability of post-weaning production of steer calves from these systems could be influenced by the length of time in the feedlot and, potentially, carcass composition. A number of authors have found age at weaning to affect efficiency of gain in feedlot steers (Fluharty et al., 2000; Barker-Neef et al., 2001; Schoonmaker et al., 2002). Date of calving may have less of an effect; Pang et al. (1998) reported that male calves born in Alberta in either April or May and June did not differ in post-weaning gain. Lardy et al. (1998) reported no effect of spring vs. summer calving season on post-weaning ADG or feed efficiency of steers, but post-weaning management of summer-born steers did influence several carcass traits. Little other research is available on the effects of altered calving systems on post-weaning performance and carcass quality in steers. This study was conducted to determine the postweaning production characteristics of beef steers from late winter, early spring, and late spring calving systems with varied weaning times in the Northern Great Plains.

\section{Materials and Methods}

The 3-yr study was conducted at the Fort Keogh Livestock and Range Research Laboratory near Miles City, MT $\left(46^{\circ} 22^{\prime} \mathrm{N} 105^{\circ} 5^{\prime} \mathrm{W}\right)$. Steers $(\mathrm{n}=$ 220; approximately 12 steers per calving-weaning treatment per year) were born in 1 of 3 calving systems: late winter $(\mathbf{L W}$; average $=$ February 8 , range = January 21 to March $3 ; \mathrm{n}=$ 74), early spring $(\mathbf{E S}$; average $=$ April 5, range $=$ March 15 to May $4 ; \mathrm{n}=$ 
74), or late spring (LS; average = May 31 , range = May 16 to Jun 26; $\mathrm{n}=$ 72). Crossbred cows were bred by natural service to bulls from a composite herd (1/2 Red Angus, 1/4 Tarentaise, and $1 / 4$ Charolais) during a 32-d breeding season. Each calving season had 2 weaning times: 190 (LW190, ES190) or 240 (LW240, ES240) d of age for LW and ES steers or 140 (LS140) or $190 \mathrm{~d}$ of age (LS190) for LS steers. Before weaning, cow-calf pairs grazed native rangeland.

Steer calves were castrated and received a 7-way clostridial vaccination (Electroid 7, Schering-Plough Animal Health, Kenilwoth, NJ) at about 6 to 8 wk of age. Steers also received a 7way clostridial vaccine and vaccination against Haemophilus somnus, bovine respiratory syncytial virus, infectious bovine rhinotracheitis, bovine viral diarrhea, and parainfluenza 3 (Vira Shield 5 + Somnus, Grand Laboratories, Inc., Larchwood, IA) at about 3 wk before weaning and at weaning. Calves received a pour-on (Ivomec, Merial, Duluth, GA) for parasites at weaning. Steers did not receive any implants during their lifetime. A full description of the pre-weaning management and calf performance can be found in Grings et al. (2005). All procedures used in this experiment followed the recommendations of the Consortium (1988) and were approved by the USDA-ARS Livestock and Range Research Laboratory Animal Care and Use Committee.

At weaning, steers were immediately transported to feeding facilities (within 5 miles) where they received (as-fed basis) 20\% long-stemmed hay, $20 \%$ barley, 55\% corn silage, and 5\% protein-mineral supplement for an average of $4 \mathrm{~d}$ followed by a diet (as-fed basis) of $75 \%$ corn silage, $10 \%$ ground alfalfa hay, 10\% barley, and $5 \%$ protein-mineral supplement for an average of $8 \mathrm{~d}$. Steers were then weighed early in the morning approximately $24 \mathrm{hr}$ after feeding. Steers were placed in one pen for each calving season with approximately 12 steers per calving system-weaning age combination used each year. Contem-

TABLE 1. Diets fed to steers during growing and finishing phases.

\begin{tabular}{|c|c|c|}
\hline Item & Growing & Finishing \\
\hline Ingredient & \multicolumn{2}{|c|}{$\%$ of DM } \\
\hline Corn silage & 62.5 & 16.5 \\
\hline Rolled barley & 19.4 & 39.5 \\
\hline Cracked corn & - & 40.7 \\
\hline Alfalfa hay & 14.8 & - \\
\hline Soybean meal & 2.3 & 1.3 \\
\hline Limestone & 0.3 & 1.4 \\
\hline Urea & 0.5 & 0.3 \\
\hline Salt & 0.1 & 0.2 \\
\hline Trace mineral mix ${ }^{a}$ & 0.03 & 0.04 \\
\hline Vitamins $A, D, E^{b}$ & 0.04 & 0.04 \\
\hline \multicolumn{3}{|l|}{ Chemical analyses } \\
\hline DM, \% & 39.8 & 65.5 \\
\hline$C P, \%$ of $D M$ & 11.7 & 10.8 \\
\hline$A D F, \%$ of $D M$ & 25.7 & 12.3 \\
\hline
\end{tabular}

${ }^{a}$ Contained $20.0 \% \mathrm{Mg}, 0.2 \% \mathrm{~K}, 2.6 \% \mathrm{~S}, 18,000 \mathrm{mg} / \mathrm{kg} \mathrm{Cu}, 60,000 \mathrm{mg} / \mathrm{kg} \mathrm{Zn}$, $40,000 \mathrm{mg} / \mathrm{kg} \mathrm{Fe}, 300 \mathrm{mg} / \mathrm{kg} \mathrm{Se}, 60,000 \mathrm{mg} / \mathrm{kg} \mathrm{Mn}, 180 \mathrm{mg} / \mathrm{kg} \mathrm{Co}$, and 1,140 $\mathrm{mg} / \mathrm{kg} \mathrm{I}$

${ }^{b}$ Contained 4,400,000 USP units/kg vitamin A, 440,000 USP units/kg vitamin D, and 220 USP units/kg vitamin $\mathrm{E}$.

poraries of these steers were shipped to Oklahoma for other studies (Phillips et al., 2006).

A corn silage-based diet (Table 1) was provided to each pen during the growing period. Steers were weighed monthly unless a treatment group was close to averaging $375 \mathrm{~kg} \mathrm{BW}$, in which case that group was weighed weekly to determine if they had reached the target BW. Steers were housed in one pen per calving system until a treatment group (calving system and weaning age combination) reached the target BW of $375 \mathrm{~kg}$, at which time they were moved to an individual feeding facility and trained to work electronic head gates. Steers were shifted to a diet of greater energy concentration (Table 1) at a group average of $422 \mathrm{~kg}$ BW. While in the individual feeding facility, daily feed delivered to each steer was recorded and feed was adjusted daily to supply intake with minimal to no orts. Each week steers were visually appraised and allotted to harvest based upon visual estimates of degree of fat cover, with the goal to slaugh- ter at approximately $1 \mathrm{~cm}$ fat thickness over the longissimus.

Samples of mixed diets were collected weekly and DM determined. Samples were ground to pass a 1-mm screen. Diet composites were made for the entire feeding period of each diet and were analyzed by wet chemistry (AOAC, 1990) for DM, ash, CP, and $\mathrm{ADF}$ at a commercial laboratory (Iowa Testing Laboratories, Inc. Eagle Grove, IA). Feed efficiency was calculated from BW gain and average daily DM intake while on the finishing diet. Because days from weaning to the start of the growing period were not equal among treatments and years, we calculated total days on test from weaning to harvest.

Steers were sent to a local abattoir for harvest. Hot carcass weight was measured the day of slaughter and other carcass measures were taken after $48 \mathrm{~h}$ storage at $2^{\circ} \mathrm{C}$. Longissimus area between the 12th and 13th sternal ribs was measured using a planar grid. Fat thickness over the longissimus was taken at the 12th rib. The kidney, pelvic, and heart fat was visu- 
ally estimated and recorded as a percentage of carcass weight. Marbling was evaluated by subjective comparison of the amount of fat within the longissimus between the 12th and 13th ribs with photographic standards (National Livestock and Meat Board, 1981). Yield grade was calculated from fat thickness, percent kidney, pelvic, and heart fat, hot carcass weight, and longissimus area using the equations of USDA (1997).

Calving system and weaning assignments were assumed to create 6 treatments. Data were analyzed using mixed model procedures (SAS Inst. Inc., Cary, NC) with treatment as a fixed effect and year and year $\times$ treatment evaluated as random effects with individual steer as the experimental unit. Treatment effects were tested using mean square for treatment $\times$ year with 10 degrees of freedom. When a significant F-test $(P<$ $0.10)$ was observed, the following contrasts were used to delineate treatment effects: 1) the average of LW190 and LW240 vs. the average of ES190 and ES240; 2) LW190 vs. ES190; 3) LS190 vs. the average of LW190 and ES190; 4) the average of LW190 and ES190 vs. LW240 and ES240; 5) LS140 vs. LS190; and 6) the linear effect of weaning in October (LW240, ES190, and LS140).

\section{Results and Discussion}

Steer BW at the beginning of the grower period averaged $241 \pm 9 \mathrm{~kg}$ and was affected by calving system and weaning strategy (Table 2). The LS190 steers weighed $24 \pm 10 \mathrm{~kg}$ less $(P<0.05)$ than the average of LW190 and ES190. This lighter initial BW for the LS190 steers at an equivalent age to LW190 and ES190 is likely related to poorer forage quality during late autumn compared to late summer and early autumn forage conditions for growth of the LW and ES steers (Grings et al., 2005). The LW190 and ES190 steers averaged $26 \pm 8 \mathrm{~kg}$ less $(P<0.01)$ than LW240 and ES240 steers. The LS140 steers weighed $26 \pm$
$11 \mathrm{~kg}$ less $(P<0.05)$ than LS190 steers.

No treatment differences $(P>0.10)$ in ADG during the growing or finishing phases (Table 2) were observed. Feed intake and efficiency of BW gain during the finishing period also did not differ $(P>0.10)$ by treatment. Feed efficiency during the growing phase was not measured. Results are consistent with Pang et al. (1998) who reported no difference in postweaning ADG in male calves born in early or late spring and with Lardy et al. (1998) who reported no effect of spring vs. summer calving season on post-weaning ADG or feed efficiency. Feed efficiency has been reported to be improved in early weaned cattle (Myers et al., 1999a,b; Story et al., 2000; Shoonmaker et al., 2002), but this may be related to lighter weights and decreased maintenance energy requirements of early weaned calves early in the growing phase. Feed efficiency in this study was not measured until the finishing phase when steers were placed in an individual feeding facility. All groups of cattle were placed on finishing diets (Table 1) at similar weights after a growing period, so an effect on feed efficiency may not be expected under the conditions of our study. More similar to our results are those of Arthington et al. (2005) who reported similar feed efficiency, BW gain, and feed intake during the finishing period in early and normal weaned calves that were similar in BW at the beginning of the finishing period. Steer age at weaning in many of these early weaning studies was much younger (about $90 \mathrm{~d}$ of age) than the younger weaning ages (140 or $190 \mathrm{~d}$ of age) in our study. Steers from all treatments were fed common growing and finishing diets (Table 1) in this study. Some research on weaning age has included feeding different diets to calves weaned at younger ages to account for differences in nutrient requirements for cattle of differing weight and, presumably, composition of BW gain. A primary goal in our research was to evaluate the effects of varied calving systems on beef production and, therefore, we chose to compare steers from the differing calving systems on a common diet. Lighter, younger steers require a greater percentage of $\mathrm{CP}$ in their diet than heavier, older steers (NRC, 1996). Although percent $\mathrm{CP}$ in the diet could be a greater limitation for the steers weaned at younger ages, there was no difference in ADG among the age groups over the entire growing period. In a commercial setting, feeding diets of varied composition to calves from LS calving systems may be an alternative to compensate for lighter weights when entering the feedlot.

Total days from weaning to harvest averaged $291 \pm 10 \mathrm{~d}$. Total days to harvest for LW190 and ES190 steers was $37 \mathrm{~d}$ longer $(P<0.01)$ in the feedlot compared to LW240 and ES240 steers. Total days to harvest are artificially elevated in this study because of the time required to adapt steers to electronic head gates between the growing and finishing periods. It took approximately $54 \mathrm{~d}$ for steers to train to the head gates and then reach an average BW of $422 \mathrm{~kg}$ before they were shifted to a more energy dense diet.

Steers were harvested at an average of $497 \pm 11 \mathrm{~d}$ of age, and age at harvest did not differ among treatments. Several researchers have reported that steers weaned at about 3.5 to 4 mo of age reach harvest at younger ages than steers weaned at closer to $7 \mathrm{mo}$ of age when harvested at an equivalent fat thickness (Fluharty et al., 2000; Schoonmaker et al., 2002). Fluharty et al. (2000) attributed differences in age at harvest associated with weaning age to be due to greater BW gains for early weaned calves between the early and late weaning time. Differences in weight gain did not occur between weaning times for steers weaned at different ages in our study (Grings et al., 2005), so the lack of differences in age at harvest are not unexpected.

Average calendar date of harvest ranged from June 22 for the LW190 steers to October 22 for LS190 steers. 
TABLE 2. Least-square means and standard error of means (SEM) for BW gain, days on feed, and feed efficiency during the growing and finishing periods of steers born in late winter, early spring, or late spring and weaned at 2 ages.

\begin{tabular}{|c|c|c|c|c|c|c|c|}
\hline Item & $\begin{array}{c}\text { Late } \\
\text { winter, } \\
190 \mathrm{~d} \\
\text { wean }\end{array}$ & $\begin{array}{l}\text { Late } \\
\text { winter, } \\
240 \mathrm{~d} \\
\text { wean }\end{array}$ & $\begin{array}{c}\text { Early } \\
\text { spring, } \\
190 \mathrm{~d} \\
\text { wean }\end{array}$ & $\begin{array}{l}\text { Early } \\
\text { spring, } \\
240 \mathrm{~d} \\
\text { wean }\end{array}$ & $\begin{array}{l}\text { Late } \\
\text { spring, } \\
140 \mathrm{~d} \\
\text { wean }\end{array}$ & $\begin{array}{l}\text { Late } \\
\text { spring, } \\
190 \mathrm{~d} \\
\text { wean }\end{array}$ & SEM \\
\hline $\mathrm{n}$ & 37 & 37 & 36 & 38 & 35 & 37 & - \\
\hline On test BW, $\mathrm{kg}^{\text {abcd }}$ & 243 & 272 & 238 & 261 & 190 & 216 & 1.7 \\
\hline Grower ADG, kg/d & 1.05 & 1.09 & 1.03 & 1.12 & 1.02 & 1.08 & 0.01 \\
\hline Finisher ADG, kg/d & 1.18 & 1.21 & 1.16 & 1.22 & 1.24 & 1.20 & 0.02 \\
\hline DMI during finishing, $\mathrm{kg} / \mathrm{d}$ & 7.6 & 7.4 & 7.2 & 7.9 & 7.4 & 7.6 & 0.04 \\
\hline Gain to feed, finishing phase, $\mathrm{g} / \mathrm{kg}$ DM & 0.17 & 0.16 & 0.16 & 0.15 & 0.17 & 0.15 & 0.003 \\
\hline Days on finishing diet ${ }^{\text {efgh }}$ & 123 & 117 & 86 & 96 & 92 & 116 & 1.9 \\
\hline Total days from weaning to harvest ${ }^{\text {td }}$ & 309 & 265 & 288 & 257 & 336 & 316 & 1.9 \\
\hline Age at harvest, $d$ & 499 & 515 & 488 & 505 & 476 & 511 & 1.8 \\
\hline Average calendar date of harvest & June 22 & July 8 & August 4 & August 24 & September 19 & October 22 & - \\
\hline
\end{tabular}

a Steers from late spring calving system weaned at $190 \mathrm{~d}$ of age differ from the average of steers from late winter and early spring calving systems weaned at $190 \mathrm{~d}$ of age, $P<0.05$.

bSteers from late winter and early spring calving systems and weaned at $190 \mathrm{~d}$ of age differ from steers from late winter and early spring calving systems weaned at $240 \mathrm{~d}$ of age, $P<0.01$.

'Steers from a late spring calving system weaned at $140 \mathrm{~d}$ of age differ from those weaned at $190 \mathrm{~d}$ of age, $P<0.05$.

dLinear effect of age at weaning in October (240, 190, and $140 \mathrm{~d}$ of age), $P<0.01$.

e Late winter differs from early spring calving system, $P<0.01$.

fSteers from late winter calving system and weaned at $190 \mathrm{~d}$ of age differ from steers from early spring calving system weaned at $190 \mathrm{~d}, P<0.01$.

GLinear effect of age at weaning in October (240, 190, and $140 \mathrm{~d}$ of age), $P<0.10$.

${ }^{h}$ Steers from late spring calving system weaned at $140 \mathrm{~d}$ of age differ from those weaned at $190 \mathrm{~d}$ of age, $P<0.10$.

Summer weather at the study location includes dry, hot days with night cooling. If steers were to be grown in less arid climates, a more accelerated feeding program might benefit LW190, LW240, and ES190 steers so that feeding is complete before occurrence of hot, humid weather. To avoid summer feeding of LS steers, options such as carrying these steers in summer grazing programs might be feasible. Lardy et al. (1998) reported that summer-born steers managed in a yearling program had heavier carcass weights and greater quality grades than summer-born steers in a calf-fed program. Management programs that increased carcass weight and quality grade would not be detrimental to the LS steers in our study.

Steer BW averaged $537 \pm 5 \mathrm{~kg}$ at harvest (Table 2). Neither calving system nor age at weaning affected harvest BW. This is in contrast to results of Schoonmaker et al. (2002) who found age at feedlot entry to affect harvest BW even when steers were harvested at equal fat thickness over the ribs.

Steers from the LW calving system had heavier $(P<0.01)$ hot carcass weight than steers from the ES system when averaged for both weaning times and for steers weaned at $190 \mathrm{~d}$ only. In addition, there was a linear effect $(P<0.01)$ of age at weaning in October on hot carcass weight. Reports on the effects of weaning age on hot carcass weights have suggested varied response, with some researchers reporting lesser carcass weights for steers weaned at younger ages (Fluharty et al., 2000; Barker-

Neef et al., 2001), whereas others (Myers et al., 1999a,b; Story et al., 2000) have not observed this effect.

Fat thickness over the longissimus did not differ by treatment (Table 3), indicating that visual observations were adequate for determining time of harvest at equivalent degree of fat cover for this study. Longissimus area and percentage kidney, pelvic, and heart fat were not affected by calving system or age at weaning when steers were harvested at equivalent compositional endpoints. Marbling score $(P<$ $0.01)$ and quality grade $(P<0.05)$ both decreased linearly with decreasing age at weaning in October (Table $3)$. In contrast to our findings, Schoonmaker et al. (2002) did not observe differences in either marbling score or quality grade between calves placed in the feedlot at 111 or $202 \mathrm{~d}$ of age. Coleman et al. (1993) suggested that lighter BW calves deposit fat more rapidly than heavier calves regardless of whether they are lighter due to age or feeding regimen; however, the opposite effect was observed in our study. 
TABLE 3. Least-square means and standard error of means (SEM) for carcass characteristics of steers born in late winter, early spring, or late spring and weaned at 2 ages.

\begin{tabular}{|c|c|c|c|c|c|c|c|}
\hline Item & $\begin{array}{l}\text { Late winter, } \\
190 \text { d wean }\end{array}$ & $\begin{array}{l}\text { Late winter, } \\
240 \text { d wean }\end{array}$ & $\begin{array}{l}\text { Early spring, } \\
190 \text { d wean }\end{array}$ & $\begin{array}{l}\text { Early spring, } \\
240 \text { d wean }\end{array}$ & $\begin{array}{l}\text { Late spring, } \\
140 \mathrm{~d} \text { wean }\end{array}$ & $\begin{array}{l}\text { Late spring, } \\
190 \text { d wean }\end{array}$ & SEM \\
\hline$n$ & 37 & 37 & 36 & 38 & 35 & 37 & - \\
\hline Harvest BW, kg & 563 & 540 & 522 & 532 & 526 & 531 & 2.7 \\
\hline Hot carcass weight, $\mathrm{kg}^{\mathrm{abc}}$ & 330 & 319 & 302 & 310 & 301 & 308 & 1.6 \\
\hline Fat thickness, cm & 1.15 & 0.99 & 1.02 & 0.94 & 0.85 & 0.91 & 0.02 \\
\hline Longissimus area, $\mathrm{cm}^{2}$ & 79.1 & 81.2 & 77.4 & 79.3 & 77.4 & 79.2 & 0.5 \\
\hline $\begin{array}{l}\text { Kidney, pelvic, and heart fat, } \\
\% \text { of carcass weight }\end{array}$ & 2.97 & 2.77 & 2.97 & 2.81 & 2.73 & 2.65 & 0.03 \\
\hline Marbling score ${ }^{\text {cdef }}$ & 509 & 498 & 458 & 425 & 407 & 451 & 5.9 \\
\hline Quality gradedgh & 12.7 & 12.6 & 12.4 & 11.9 & 11.8 & 12.2 & 0.06 \\
\hline Yield grade ${ }^{\mathrm{ijk}}$ & 3.08 & 2.66 & 2.80 & 2.69 & 2.54 & 2.56 & 0.02 \\
\hline
\end{tabular}

atate winter differs from early spring calving system, $P<0.01$.

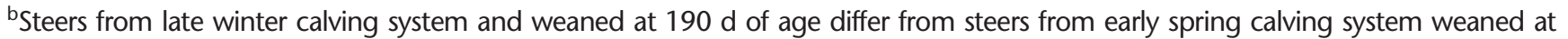
$190 \mathrm{~d}$ of age, $P<0.01$.

'Linear effect of age at weaning in October (240, 190, and $140 \mathrm{~d}$ of age), $P<0.01$.

d Late winter differs from early spring calving system, $P<0.05$.

ePractically devoid $=100$ to 199 , traces $=200$ to 299 , slight $=300$ to 399 , small $=400$ to 499 , modest $=500$ to 599 , moderate $=$ 600 to 699.

fSteers from late winter calving system and weaned at $190 \mathrm{~d}$ of age differ from steers from early spring calving system weaned at $190 \mathrm{~d}$ of age, $P<0.10$.

gPrime $+=17$, Prime $=16$, Prime $-=15$, Choice $+=14$, Choice $=13$, Choice $-=12$, Select $=11$, Standard $=10$.

hLinear effect of age at weaning in October (240, 190, and $140 \mathrm{~d}$ of age), $P<0.05$.

'Yield grade $=2.5+(2.5 \times$ adjusted fat thickness, inches $)+(0.2 \times \%$ kidney, pelvic, and heart fat $)+(0.0038 \times$ hot carcass weight, lbs) $-\left(0.32 \times\right.$ longissimus area, $\left.\mathrm{in}^{2}\right)$; USDA (1997).

jSteers from late spring calving system and weaned at $190 \mathrm{~d}$ of age differ from the average of steers from late winter and early spring calving systems weaned at $190 \mathrm{~d}$ of age, $P<0.05$.

kSteers from late winter and early spring calving systems and weaned at $190 \mathrm{~d}$ of age differ from steers from late winter and early spring calving systems weaned at $240 \mathrm{~d}$ of age, $P<0.05$.

Marbling score and quality grade were greater $(P<0.05)$ in LW than ES steers. This could be related to the greater hot carcass weights observed in steers from the LW calving system as carcass fat has been reported to relate to carcass weight (Berg and Butterfield, 1968). Several researchers have reported that marbling score does not vary with weaning age when cattle are harvested at a compositional endpoint (Myers et al., 1999b; Schoonmaker et al., 2001), whereas others have observed differences (Myers et al., 1999a). Yield grade was greater $(P<0.05)$ for the average of LW190 and ES190 compared to LS190, and yield grade was greater $(P<0.05)$ for the average of LW190 and EW190 than the average of LW240 and EW240.

\section{Implications}

Delaying calving in the Northern Great Plains until late spring while keeping weaning age at $190 \mathrm{~d}$ resulted in decreased BW of steers going into the feedlot. Calving later in the calendar year without altering weaning date produces younger calves at weaning with lighter BW at the start of the feeding period, which requires a greater number of days to harvest and produces carcasses with less marbling and lesser quality grades. It may be desirable to develop altered feeding programs for steers from LS calving systems in the Northern Great Plains that promote more rapid BW gains early in the growing period or make use of available pas- ture and forages while delaying entry into the feedlot.

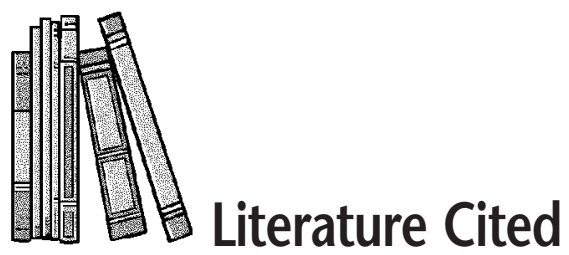

AOAC. 1990. Official Methods of Analysis, 15th ed. Assoc. of Offic. Anal. Chem., Arlington VA.

Arthington, J. D., J. W. Spears, and D. C. Miller. 2005. The effect of early weaning on feedlot performance and measures of stress in beef calves. J. Anim. Sci. 83:933.

Barker-Neef, J. M., D. D. Buskirk, J. R. Black, M. E. Doumit, and S. R. Rust. 2001. Biological and economic performance of early-weaned Angus steers. J. Anim. Sci. 79:2762.

Berg, R. T., and R. M. Butterfield. 1968. Growth patterns of bovine muscle, fat and bone. J. Anim. Sci. 27:611. 
Coleman, S. W., B. C. Evans, and J. J. Guenther. 1993. Body and carcass composition of Angus and Charolais steers as affected by age and nutrition. J. Anim. Sci. 71:86.

Consortium. 1988. Guide for Care and Use of Agricultural Animals in Agricultural Research and Teaching. Consortium for Developing a Guide for the Care and Use of Agricultural Animals in Agricultural Research and Teaching. FASS, Savoy, IL.

Fluharty, F. L., S. C. Loerch, T. B. Turner, S. J. Moeller, and G. D. Lowe. 2000. Effects of weaning age and diet on growth and carcass characteristics in steers. J. Anim. Sci. 78:1759.

Grings, E. E., R. E. Short, K. D. Klement, T. W. Geary, M. D. MacNeil, M. R. Haferkamp, and R. K. Heitschmidt. 2005. Calving date and weaning age effects on cow and preweaning calf performance in the Northern Great Plains. J. Anim. Sci. 83:2671.

Lardy, G., D. Adams, R. Clark, and T. Klopfenstein. 1998. Performance of summer- and spring-born calves finished as calves or year- lings. Nebraska Beef Rep. p 5. Univ. Nebraska, Coop. Exten. Serv., Lincoln.

Myers, S. E., D. B. Faulkner, F. A. Ireland, L. L. Berger, and D. F. Parrert. 1999a. Production systems comparing early weaning to normal weaning with or without creep feeding for beef steers. J. Anim. Sci. 77:300.

Myers, S. E., D. B. Faulkner, F. A. Ireland, and D. F. Parrett. 1999b. Comparison of three weaning ages on cow-calf performance and steer carcass traits. J. Anim. Sci. 77:323.

National Livestock and Meat Board. 1981. Official USDA Marbling Photographs. No. 8843. USDA, Chicago, IL

NRC. 1996. Nutrient Requirement of Beef Cattle. 7 th rev. ed. Natl. Acad. Sci., Washington DC.

Pang, H., M. Makarechian, L. A. Goonewardene, and R. T. Berg. 1998. Effects of early versus late spring calving on beef cow/calf productivity. Can J. Anim. Sci. 78:249.

Phillips, W. A., E. E. Grings, R. E. Short, R. K. Heitschmidt, S. W. Coleman, and H. S. May- uex. 2006. Effect of calving season on stocker and feedlot performance. Prof Anim. Sci. 22:392.

Schoonmaker, J. P., F. L. Fluharty, S. C. Loerch, T. B. Turner, S. J. Moeller, and D. M. Wuff. 2001. Effect of weaning status and implant regimen on growth, performance, and carcass characteristics in steers. J. Anim. Sci. 79:1074.

Schoonmaker, J. P., S. C. Loerch, F. L. Fluharty, H. N. Zerby, and T. B. Turner. 2002. Effect of age at feedlot entry on performance and carcass characteristics of bulls and steers. J. Anim. Sci. 80:2247.

Story, C. E., R. J. Rasby, R. T. Clark, and C. T. Milton. 2000. Age of calf at weaning of spring-calving beef cows and the effect on cow and calf performance and production economics. J. Anim. Sci. 78:1403.

USDA. 1997. United States Standards for Grades of Carcass Beef. Agric. Marketing Serv. USDA, Washington DC. 